\title{
Kwart eeuw NBW
}

\author{
Een redactionele beschouwing
}

\author{
Mr.J.A. van der Weide*
}

Hoewel het eindresultaat anders zou doen vermoeden, is de totstandkoming van het Nieuw Burgerlijk Wetboek (NBW) niet zonder slag of stoot verlopen:

'Volgens De Vries kwam het regelmatig voor dat De Jong, moedeloos geworden van het eindeloze geruzie, zijn stoel omdraaide, met zijn rug naar de anderen ging zitten en zijn hand aan het hoofd bracht. Fokkema had deze lezing: "De Jong, die meer een praktische geest was, kon het doordrammen van Eggens over bepaalde filosofische stokpaardjes niet verdragen, eenvoudig omdat het ophield. Hij had dan de neiging om een beetje voorover te gaan zitten en te doen alsof hij sliep. Hij sliep echter allerminst."'1

Codificeren is mensenwerk.

Nadat Eduard Maurits Meijers, de grondlegger van het NBW, geheel onverwacht in 1954 was komen te overlijden, werden zijn werkzaamheden voortgezet door het zogenaamde 'driemanschap Drion-Eggens-De Jong', eminente juristen in hun tijd. ${ }^{2}$ Pas 45 jaar nadat bij Koninklijk Besluit van 25 april 1947 aan professor E.M. Meijers de opdracht was gegeven een nieuw Burgerlijk Wetboek te ontwerpen, traden op 1 januari 1992 de Boeken 3, 5, 6 en een deel van Boek 7 in werking. ${ }^{3}$ De hercodificatie en modernisering van het Nederlandse vermogensrecht waren daarmee voor een belangrijk deel voltooid. Van het verouderde en op de leest van de Franse Code Civil geschoeide oude BW werd definitief afscheid genomen. Dit jaar vieren wij een kwart eeuw NBW.

Wat heeft het NBW ons zoal gebracht? Naast een eenvormig begrippenkader, een gelaagde structuur en open normen, die met name het Nederlandse verbintenissenrecht inkleuren - de zorgvuldigheidsnorm van art. 6:162 lid $2 \mathrm{BW}^{4}$ en de redelijk-

Mr. J.A. van der Weide is universitair hoofddocent aan de Universiteit Leiden en hoofdredacteur van $\mathrm{MvV}$.

1. E.O.H.P. Florijn, Ontstaan en ontwikkeling van het nieuwe Burgerlijk Wetboek (diss. Maastricht), Maastricht: Universitaire Pers Maastricht 1994, p. 220.

2. Uitgebreid over E.M. Meijers: H.J. Snijders, Eduard M. Meijers, het Nederlands BW en de wereld, AA 2010, p. 44-49.

3. Reeds eerder waren Boek 1 (1970), Boek 2 (1976) en Boek 8 (1991) in werking getreden, terwijl pas later Boek 4 (2003) en Boek 10 (2012) in werking traden.

4. Zie de 'klassieker' Lindenbaum/Cohen (HR 31 januari 1919, NJ 1919, p. 161). heids- en billijkheidstoets (Treu und Glauben) van art. 6:2 en 6:248 $\mathrm{BW}^{5}$-, werd het gesloten goederenrechtelijke stelsel voorzien van een sluitsteen in de vorm van het fiduciaverbod van art. 3:84 lid $3 \mathrm{BW}$. Het verbod is, tegen de achtergrond van de rechtspraak van de Hoge $\mathrm{Raad}^{6}{ }^{6}$ de financiële (rechts)praktijk en de invloed van het Europese richtlijnenrecht, nog immer een bron van discussie. Zo staan voor de financieringspraktijk belangrijke typen van factoring, securitisation en covered bonds-transacties ontegenzeggelijk op gespannen voet met het verbod. ${ }^{7}$ Niet alleen door ontwikkelingen van binnenuit, maar ook door invloeden van buitenaf - concreet: het Europese richtlijnenrecht ${ }^{8}$ - dreigt het fiduciaverbod zich te ontwikkelen tot een klassiek 'hoofdpijndossier'.

Wie evenwel mocht denken dat ons huidige BW fremdfeindlich of een monocultuur is, heeft het volledig mis. Bij het ontwerpen van het NBW is door Meijers, en later ook door het driemanschap, op uitgebreide schaal gebruik gemaakt van de methode van de rechtsvergelijking. Grote belangstelling en invloed genoten het Duitse en het Zwitserse recht, maar ook het Franse, Italiaanse en Griekse recht werden frequent geraadpleegd. ${ }^{9}$ Verschillende buitenlandse rechtsfiguren hebben hun intrede gedaan in het huidige BW, zoals de Engelse anticipatory breach (art. 6:80 BW), de Duitse theorie van de Schutznorm (art. 6:163 BW) en de Franse leer van de imprévision (art. 6:258 BW). De rechtsvergelijkende benadering om

5. Vgl. bijv. de 'effectenlease-arresten' (HR 5 juni 2009, ECLI:NL:HR: 2009:BH2811, ECLI:NL:HR:2009:BH2815 en ECLI:NL:HR: 2009:BH2822), waarin een uit de eisen van redelijkheid en billijkheid voortvloeiende bijzondere zorgplicht van financiële instellingen jegens particuliere wederpartijen werd aangenomen bij het aangaan van overeenkomsten met betrekking tot financiële producten.

6. HR 19 mei 1995, NJ 1996/119 m.nt. WMK (Keereweer q.q./Sogelease), alsmede HR 18 november 2005, NJ 2006/151 (BTL Lease/Van Summeren). Zie tevens recentelijk Rb. Midden-Nederland 30 maart 2016, ECLI:NL:RBMNE:2016:1547 (gepubliceerd op 10 november 2017).

7. Zie reeds W.A.K. Rank, De (on)hanteerbaarheid van het Nederlandse recht voor de moderne financiële praktijk (oratie Nijmegen; Serie Onderneming en Recht, deel 12), Deventer: W.E.J. Tjeenk Willink 1998, alsmede uitgebreid: M.H.E. Rongen, Cessie (diss. Nijmegen; Serie Onderneming en Recht, deel 70), Deventer: Kluwer 2012, hoofdstuk VII.

8. Richtlijn 2002/47/EG van 6 juni 2002 betreffende financiëlezekerheidsovereenkomsten (PbEG 2002, L 168/43), die heeft geleid tot art. 7:55 BW, waarin is bepaald dat een 'fzo' tot overdracht geen overdracht is in de zin van art. 3:84 lid 3 BW.

9. Uitgebreid: V.J.A. Sütő, Nieuw vermogensrecht en rechtsvergelijking reconstructie van een wetgevingsproces (1947-1961) (diss. Leiden), Den Haag: Boom Juridische uitgevers 2004. 


\section{Maandblad}

tot hercodificatie te komen is een beproefde methode. Niet voor niets wordt deze methode ook gevolgd in de recentelijk gepubliceerde hervormingsvoorstellen van het Belgische Burgerlijk Wetboek, waarbij expliciet wordt verwezen naar onder meer het Nederlandse BW. ${ }^{10}$

Inmiddels heeft het Europees privaatrecht - waartoe voor het gemak ook de regels van internationaal privaatrecht worden gerekend - een hoge vlucht genomen. ${ }^{11} \mathrm{Via}$ de boeg van (thans) art. 288 van het Verdrag betreffende de werking van de Europese Unie maakt de EU veelvuldig gebruik van haar bevoegdheid tot het vaststellen van richtlijnen en verordeningen. Wie had pakweg vijftig jaar geleden kunnen vermoeden dat het Nederlandse privaatrecht (lees: het BW), en in het bijzonder het Nederlandse consumenten- en contractenrecht, zo doordesemd zou geraken van regels van Europese origine? En dat het opereren binnen een 'meerlagige rechtsorde'12 en de bestudering van de rechtspraak van het Hof van Justitie van de Europese Unie zouden gaan behoren tot de natuurlijke habitat van de Nederlandse privatist? ${ }^{13}$ Het Europese regelkader heeft het Nederlandse privaatrecht in een niet-geringe mate beïnvloed en zal dat ook blijven doen. Brexit of geen Brexit: de Brusselse trein rijdt door. ${ }^{14}$

Met gepaste trots mogen we terugkijken op 25 jaar NBW. De ontwerpers bezorgden ons een coherente vermogensrechtelijke codificatie die voldoet aan de eisen van de moderne tijd. Tegelijkertijd is een waarschuwend woord op zijn plaats. Mede onder invloed van de Europese regelgeving ligt verbrokkeling op de loer, die de coherentie en consistentie van het BW ondergraaft. Implementatie van het Europese richtlijnenrecht vindt soms op een manier plaats die én geen recht doet aan de betrokken richtlijn én deze niet goed inpast in de Nederlandse rechtssystematiek. Treffende voorbeelden hiervan zijn de implementatie van de al eerder gememoreerde richtlijn van 6 juni 2002 betreffende financiëlezekerheidsover- eenkomsten ${ }^{15}$ en de richtlijn van 13 november 2007 betreffende betalingsdiensten in de interne markt. ${ }^{16}$

Op verzoek van de redactie van het Maandblad voor Vermogensrecht heeft Henk Snijders, honorair hoogleraar Burgerlijk recht en burgerlijk procesrecht aan de Universiteit Leiden, gereflecteerd op een kwart eeuw NBW. Snijders heeft, met één oog turend in de achteruitkijkspiegel, de blik naar voren gericht en houdt - tegen de achtergrond van de Brexit - in zijn bijdrage een krachtig pleidooi voor een Europese codificatie van het burgerlijk recht in de vorm van een European Civil Code (ECC), een Europees Burgerlijk Wetboek. Het is een prikkelende gedachte die, de tegenkrachten binnen de verschillende EU-lidstaten ten spijt, serieuze overdenking verdient.

De redactie van het Maandblad voor Vermogensrecht zal de ontwikkeling van het BW en die van het Nederlandse vermogensrecht in brede zin op constructieve en kritische wijze blijven volgen. Langs deze weg hoopt de redactie bij te kunnen dragen aan de rechtsvormende taak van de privaatrechtelijke doctrine. Ook in de komende 25 jaar.

Namens de redactie van $\mathrm{MvV}$,

Jeroen van der Weide (hoofdredacteur)
10. Zie justitie.belgium.be/sites/default/files/expose_des_motifs-_le_droit_ des_biens.pdf.

11. Zie o.a. Asser/Hartkamp 3-I, Vermogensrecht algemeen. Europees recht en Nederlands vermogensrecht, Deventer: Wolters Kluwer 2015.

12. Zie over deze 'meergelaagdheid' o.a. W. van Gerven \& S. Lierman, Algemeen Deel. Veertig jaar later. Privaat- en publiekrecht in een meergelaagd kader van regelgeving, rechtsvorming en regeltoepassing, Mechelen: Kluwer 2010, alsmede R. Westrik, Verborgen privaatrecht. Hoe het geldende recht te kennen?, Zutphen: Uitgeverij Paris 2016.

13. Bijv. de rechtspraak van het Hof van Justitie over de ambtshalve toetsing van oneerlijke bedingen en het naar aanleiding daarvan in november 2014 verschenen herziene rapport van de LOVCK werkgroep, te raadplegen via www.rechtspraak.nl/SiteCollectionDocuments/Rapportambtshalve-toetsing-II-versie-november-2014.pdf.

14. Zie tevens de observaties van Snijders in zijn bijdrage aan dit nummer (H.J. Snijders, NBW-vermogensrecht 25 jaar, MvV 2017, afl. 12).

15. Zie noot 8. Vgl. tevens F.E.J. Beekhoven van den Boezem, Richtlijn 2009/44/EG: EG-knuppel in het hoenderhok van het Nederlandse goederenrecht, MvV 2009, p. 315-317, alsmede P. Heemskerk, De wet tot implementatie van de FZO-wijzigingsrichtlijn (2009/44/EG): zekerheid over zekerheid, MvV 2011, p. 144-149.
16. Richtlijn 2007/64/EG van 13 november 2007 betreffende betalingsdiensten in de interne markt (PbEU 2007, L 319/1). Kritisch: H.N. Schelhaas, Inconsistenties in het verbintenissenrecht: de wetswijziging betaaldiensten, NTBR 2010, p. 1. 